\begin{tabular}{l|l|l|l} 
Case Reports in & $\begin{array}{l}\text { Case Rep Dermatol 2009;1:66-70 } \\
\text { D01: } 10.1159 / 000249150\end{array}$ & Published online: October 27, 2009 & $\begin{array}{l}\text { 2009 S. Karger AG, Basel } \\
\text { ISSN 1662-6567 } \\
\text { www.karger.com/cde }\end{array}$ \\
\hline
\end{tabular}

\title{
Coma Blisters
}

\author{
Joana Rocha ${ }^{a}$ Teresa Pereira $^{a} \quad$ Filipa Ventura ${ }^{a}$ \\ Fernando Pardal ${ }^{\mathrm{b}} \quad$ Celeste Brito $^{\mathrm{a}}$ \\ Departments of a Dermatology and ' ${ }^{\mathrm{b}}$ Pathology, Hospital de São Marcos, Braga, \\ Portugal
}

\section{Key Words}

Coma $\cdot$ Blister $\cdot$ Barbiturate $\cdot$ Overdose $\cdot$ Meningoencephalitis

\begin{abstract}
Coma blisters are lesions that occur in the setting of a variety of neurological diseases. Although most commonly associated with barbiturate overdose, they can be seen in the setting of coma due to other etiologies. Blisters develop 48-72 $\mathrm{h}$ after the onset of unconsciousness. We report the case of a 29-year-old man who presented to the emergency department with confusion and progressive loss of consciousness. He had high serum glucose, abnormal hepatic and kidney function tests and a normal toxicological screening. $24 \mathrm{~h}$ after admission he was comatose and was started on antibiotics for presumed bacterial meningoencephalitis. Two days after the onset of coma, multiple tense hemorrhagic blisters appeared on the patient's extremities. Skin biopsy revealed an intraepidermal blister with variable degrees of epidermal necrosis. Five days later the patient was fully recovered with no neurological sequelae. No topical treatment was necessary, with complete resolution of the skin lesions two weeks later.
\end{abstract}

\section{Introduction}

Coma blisters are characteristic lesions that occur in the setting of a variety of neurological diseases. Although traditionally associated with barbiturate overdose, they can be seen in the setting of coma due to other etiologies $[1,2]$. We present the case of a comatose patient with bullous skin lesions and no history of drug overdosage.

\section{Case Report}

A 29-year-old previously healthy Caucasian man with an unremarkable past medical history and no drug abuse presented to the emergency department with confusion and progressive loss of consciousness. There was no history of recent use of any medications.

On admission he was febrile $\left(38^{\circ} \mathrm{C}\right)$ with a Glasgow Coma Scale score of $8(4 / 2 / 2)$ and no cutaneous lesions. Blood analysis revealed abnormal serum glucose (560 mg/dl), hepatic (AST $67 \mathrm{U} / \mathrm{l}$; ALT $70 \mathrm{U} / \mathrm{l}$ ) and renal dysfunction (creatinine $1.6 \mathrm{mg} / \mathrm{dl}$; urea $84 \mathrm{mg} / \mathrm{dl}$ ), and elevated white blood cell count 


\begin{tabular}{c|l|l|l} 
Case Reports in & $\begin{array}{l}\text { Case Rep Dermatol 2009;1:66-70 } \\
\text { Dol: } 10.1159 / 000249150\end{array}$ & Published online: October 27, 2009 & $\begin{array}{l}\text { ○ 2009 S. Karger AG, Basel } \\
\text { ISSN 1662-6567 } \\
\text { www.karger.com/cde }\end{array}$ \\
\hline
\end{tabular}

$(11,800 / \mathrm{l})$ and C-reactive protein $(391 \mathrm{mg} / \mathrm{l})$. Toxicological screening was negative. A lumbar puncture was done and the cerebrospinal fluid analysis revealed signs of bacterial meningitis. Brain CT scan was also consistent with infectious meningoencephalitis, but the causative organism was not identified. He was transferred to the Neurology Department with presumed bacterial meningoencephalitis in a deeply comatose condition, under cefotaxime ( 2 g i.v. $\mathrm{q} 4 \mathrm{~h}$ ), ampicillin ( $2 \mathrm{~g}$ i.v. $\mathrm{q} 4 \mathrm{~h}$ ) and dexamethasone (10 $\mathrm{mg}$ i.v. q8h) therapy.

Two days later, multiple tense hemorrhagic blisters with normal-appearing adjacent skin appeared on the patient's extremities (fig. 1). A skin biopsy was performed and revealed an intraepidermal (subcorneal) blister and partially to frankly necrotic epidermis with a mild inflammatory infiltrate in the adjacent dermis (fig. 2). Thrombosis of the vessels in the lower dermis was observed with occlusion of the lumen by fibrinoid eosinophilic thrombi and red cell extravasation into the surrounding dermis (fig. 3). There was no eccrine sweat gland necrosis.

Five days later the patient had recovered completely without neurological sequelae. During his hospital stay a concurrent diagnosis of diabetes mellitus was made, with good glycemic control under insulin therapy. No topical treatment was necessary and the skin lesions resolved completely within two weeks.

\section{Discussion}

The exact pathogenesis of coma blisters is still unclear, but hypoxia and external pressure seem to be pivotal factors. Although drug overdose is the most frequent predisposing event, lesions cannot be related specifically to the toxic effects of any medication [1]. A possible explanation is that bullae are caused by uninterrupted pressure exacerbated by arterial hypotension due to shock or vasoactive drugs [1].

Pressure-induced local ischemia seemingly leads directly to tissue injury proportional to the amount and duration of pressure. Local anoxia causes a necrotic bulla and the typical selective destruction of the most metabolically active cells (eccrine sweat glands) [2]. Recent studies suggest that immune mechanisms are also implicated in the pathogenesis of this condition [3].

Blisters usually develop within $48-72 \mathrm{~h}$ after the onset of unconsciousness and tend to occur in pressure sites. They are self-limited lesions that heal spontaneously over 1 or 2 weeks. The clinical setting alone is usually sufficient for diagnosis, but there are characteristic histological findings that may aid [4]. Histological findings include not only subepidermal bullae but also focal necrosis of epidermis, dermis, subcutaneous tissue and all epidermal appendages [5]. Eccrine sweat gland and sweat duct necrosis is the most remarkable and significant change [6], but its absence does not exclude the diagnosis. The absence of inflammatory infiltrate in the epidermis and the presence of thrombosis in dermal vessels are the most important markers of non-drug-induced coma blisters [4]. Although the role of immunofluorescence studies in the biopsy specimen is not well established, there are studies that show deposits of immunoglobulins and/or complement in non-drug-induced coma blisters [3-5].

Although our patient presented with the typical findings of non-drug-induced coma blisters, we could not exclude with certainty the diagnosis of bullosis diabeticorum. The majority of patients with this condition are long-standing diabetics with associated polyneuropathy, retinopathy and/or nephropathy, but bullosis diabeticorum has been rarely described as the presenting sign of diabetes [7].

The management of the patient with coma blisters should take into account the benign nature of this condition, which is not related to any underlying infectious process and does not contraindicate continuation of any therapy. There is no known risk of progression to toxic epidermal necrolysis [2]. 


\begin{tabular}{c|l|l|l}
$\begin{array}{c}\text { Case Reports in } \\
\text { Denmitolagy }\end{array}$ & $\begin{array}{l}\text { Case Rep Dermatol 2009;1:66-70 } \\
\text { D0I: } 10.1159 / 000249150\end{array}$ & Published online: October 27, 2009 & $\begin{array}{l}\text { O 2009 S. Karger AG, Basel } \\
\text { ISSN 1662-6567 } \\
\text { www.karger.com/cde }\end{array}$ \\
\hline
\end{tabular}

Fig. 1. Tense hemorrhagic blisters on the patient's fingers and toes.

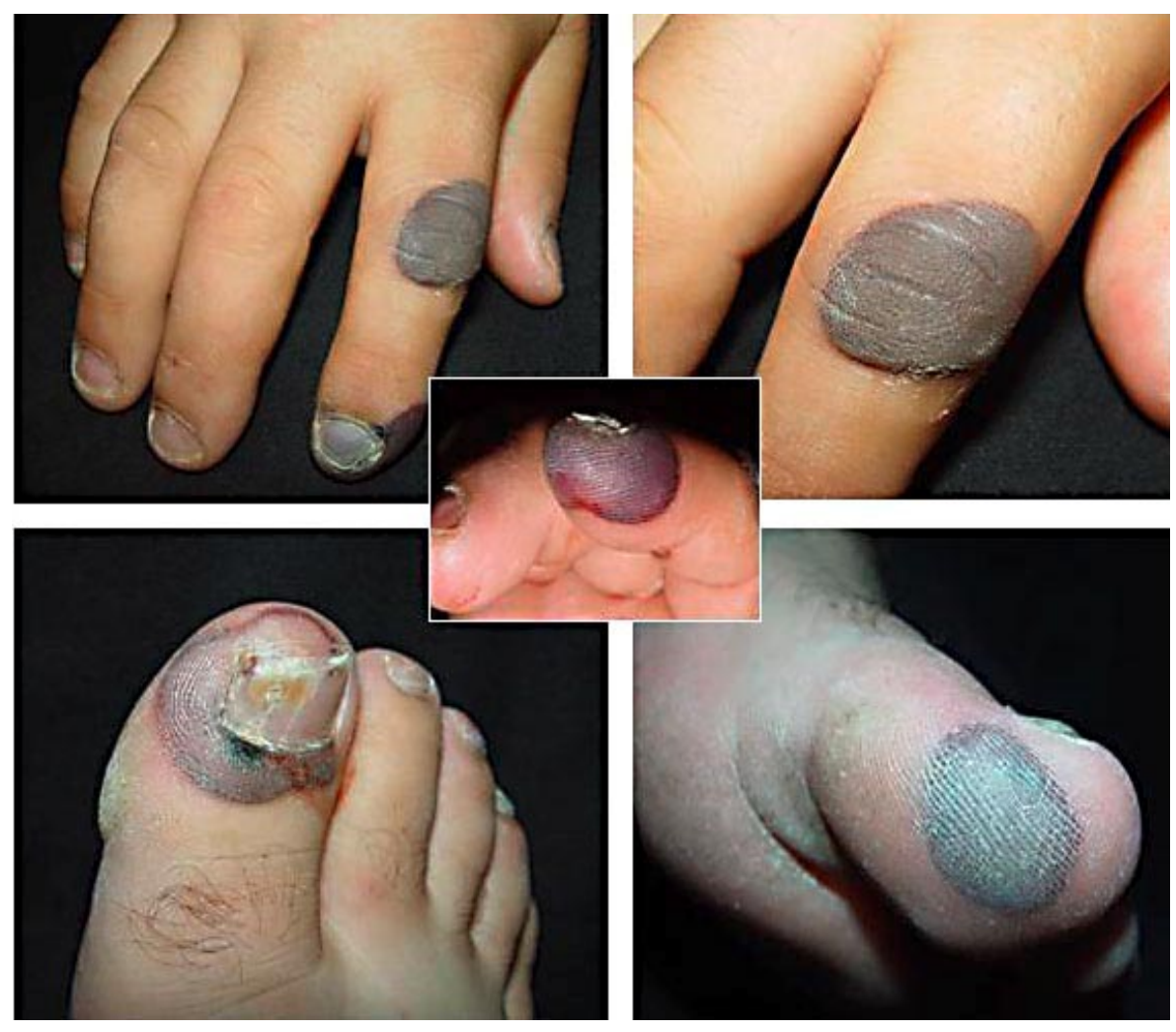

Fig. 2. Intraepidermal blister and necrotic epidermis with mild inflammatory infiltrate. Hematoxylin \& eosin, $\times 40$.

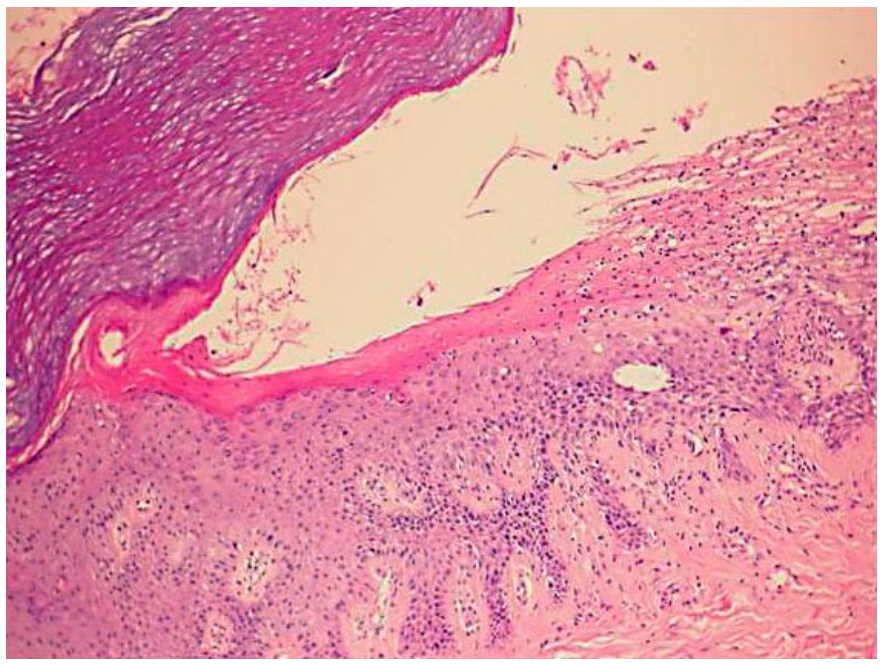


Fig. 3. Thrombosis of the vessels in the lower dermis with occlusion of the lumen by fibrinoid eosinophilic thrombi and red cell extravasation into the surrounding dermis. Hematoxylin \& eosin, $\times 400$.

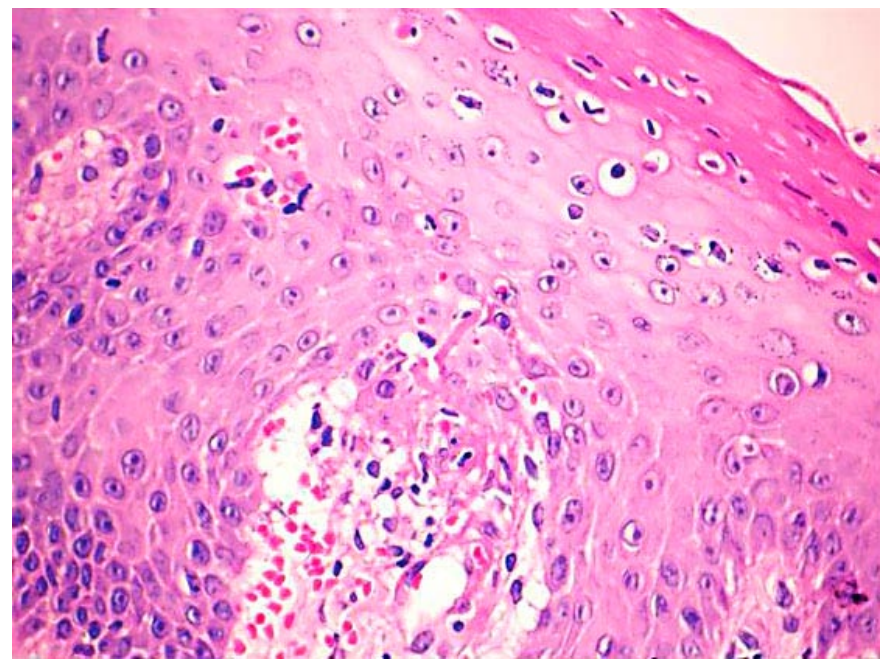




\section{References}

1 Arndt KA, Mihm MC, Parrish JA: Bullae: a cutaneous sign of neurologic diseases. J Invest Dermatol 1973;66:312-320.

-2 Dunn C, Held JL, Spitz J, Silvers DN, Grossman ME, Kohn SR: Coma blisters: report and review. Cutis 1990;45:423-426.

-3 Reiley GD, Harrington CI: Positive immunofluorescence in bullous lesions in drug-induced coma. Br J Dermatol 1983;109:720-724.

4 Kato N, Ueno H, Mimura M: Histopathology of cutaneous changes in non-drug-induced coma. Am J Dermatopathol 1996;18:344-350.

5 Arndt KA: Bullae in comatose and non-comatose patients. Acta Derm Venereol 2003;83:236-237.

6 Kim KJ, Suh HS, Choi JH, Sung KJ, Moon KC, Koh JK: Two cases of coma-associated bulla with eccrine gland necrosis in patients without drug intoxication. Acta Derm Venereol 2002;82:378-380.

7 Derighetti M, Hohl D, Krayenbuhl BH, Panizzon RG: Bullosis diabeticorum in a newly discovered type 2 diabetes mellitus. Dermatology 2000;200:266-267. 